\title{
Soft sediment meiofaunal community structure in relation to a long-term heavy metal gradient in the Fal estuary system
}

\author{
P. J. Somerfield, J. M. Gee, R. M. Warwick \\ Plymouth Marine Laboratory, Prospect Place, The Hoe, Plymouth PL1 3DH, United Kingdom
}

\begin{abstract}
The Fal estuary system, southwest England, is an ideal site for a natural experiment on the effects of long-term contamination by heavy metals on intertidal mudflat meiofauna communities. Five creeks were chosen in which sediment concentrations of heavy metals differed by orders of magnitude, namely Restronguet (mean Cu concentration $\left.2532 \mu \mathrm{g} \mathrm{g}^{-1}\right)$, Mylor $\left(1272 \mu \mathrm{g} \mathrm{g}^{-1}\right)$, Pill $\left(697 \mu \mathrm{g} \mathrm{g}^{-1}\right)$, St Just in Roseland $\left(332 \mu \mathrm{g} \mathrm{g}^{-1}\right)$ and Percuil $\left(165 \mu \mathrm{g} \mathrm{g}^{-1}\right)$. Univariate and multivariate analyses of the meiofaunal community structure in these creeks suggest that nematodes are more responsive to sediment heavy metal concentrations than copepods, as indices of diversity and changes in nematode community structure as revealed by multivariate analyses were closely correlated with metal levels. For copepods differences could only be detected in Restronguet creek, where endobenthic species were absent. Analyses suggest that some nematode species may have developed different tolerance mechanisms for survival in areas with high heavy metal concentrations.
\end{abstract}

KEY WORDS: Heavy metals $\cdot$ Sediment $\cdot$ Meiofauna $\cdot$ Nematodes $\cdot$ Copepods

\section{INTRODUCTION}

Meiofauna have evoked considerable interest as potential indicators of anthropogenic perturbation in aquatic ecosystems (see review by Coull \& Chandler 1992) as they have several potential advantages over macrofauna, which have traditionally been the component of the benthos examined in pollution monitoring surveys. These include their small size and high densities, so that smaller samples may be collected, shorter generation times and no planktonic phase in their life cycles, suggesting a potentially shorter response time and higher sensitivity to anthropogenic disturbance (Heip et al. 1988, Warwick 1993). Heavy metals are an important component in many marine discharges, including sewage, industrial wastes and mining wastes (Bryan 1976). Although sediment metal concentrations have been implicated in pollution effects in the meiobenthos (Tietjen 1980, Gee et al. 1992) few discharges to the sea alter sediment metal concentrations in isolation and it is therefore difficult to separate the toxic effects of heavy metals from, for example, organic enrichment.

The Fal estuary system in Cornwall, UK, contains a number of tidal creeks which open into Carrick Roads (Fig. 1). Each of these has a small central stream and extensive areas of mudflats. The mining of metals in the area of southwest Cornwall drained by the Carnon River, which enters Carrick Roads via Restronguet Creek (Fig. 1), has a long history, probably stretching back to the Bronze Age for the recovery of alluvial tin. In the middle of the 19th century more than 1000 mines produced up to $50 \%$ of the world's supply of copper, tin and arsenic. Output declined sharply during the 20 th century and the last tin mine, Wheal Jane in the Carnon Valley, closed in 1991. Heavy metals, however, have continued to enter the Carnon River from old mine adits and runoff from spoil heaps. Thus over the centuries a marked gradient of sediment metal concentrations has built up and sediments in otherwise similar creeks in different parts of the system have levels of heavy metals (including $\mathrm{Cu}, \mathrm{Zn}, \mathrm{As}, \mathrm{Cd}, \mathrm{Fe}$ ) which differ by orders of magnitude (Bryan \& Gibbs 1983). 


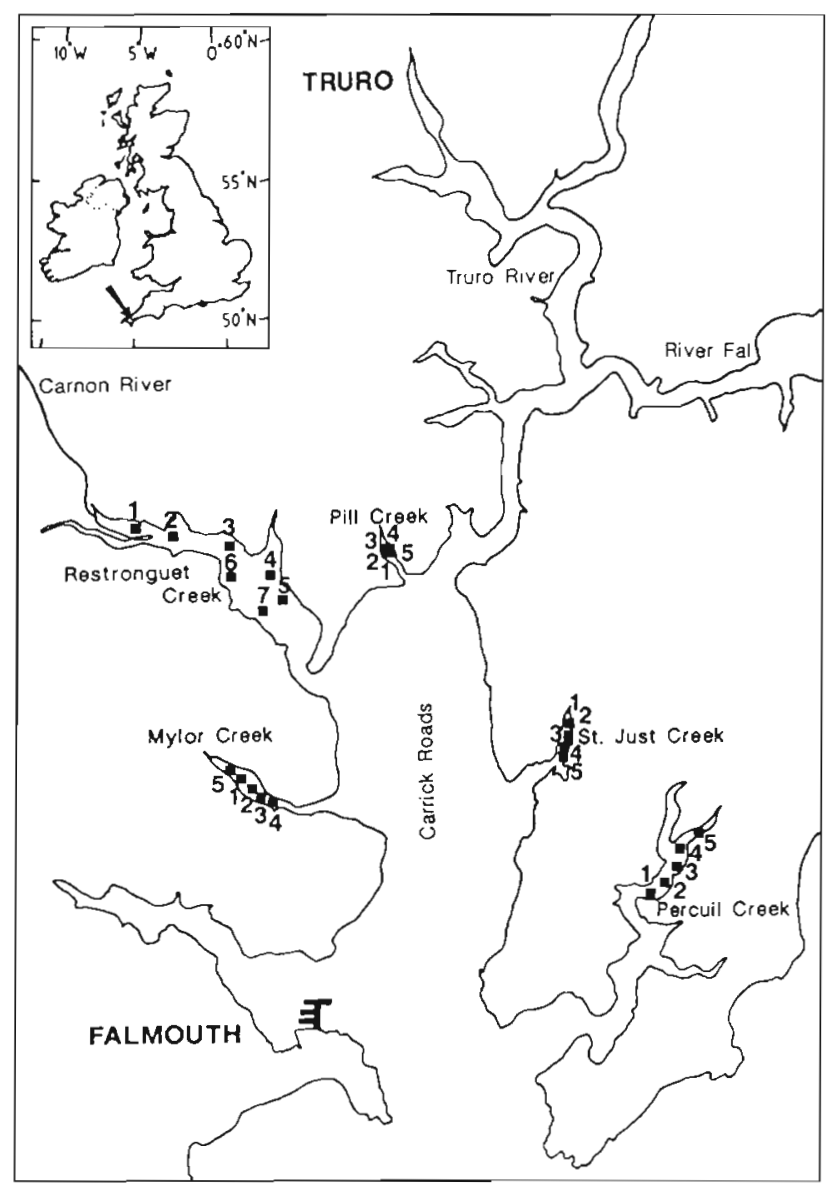

Fig. 1 Sampling locations within the Fal estuary system, Cornwall, UK

The Fal estuary system, therefore, presented a suitable site for a natural experiment on the effects of longterm heavy metal pollution on meiofaunal community structure in an area otherwise subjected to a very low level of pollution.

\section{MATERIAL AND METHODS}

Sampling design. Based on sediment copper data in Bryan \& Gibbs (1983), 5 creeks (Restronguet, Mylor, Pill, St Just in Roseland and Percuil) entering into Carrick Roads were chosen to cover the expected range of heavy metal concentrations. Replication in the sampling design was on a spatial scale appropriate to examining differences between creeks. In November 1991, 5 sites (7 in Restronguet) along each creek were selected as representative of that creek and, being at the same tidal height (distance from the central stream) and confined to banks of mud, as far as possible with similar environmental characteristics. At each location (Fig. 1) a single core $(50 \mathrm{ml}$ syringe to a depth of $5 \mathrm{~cm}$ ) was taken for meiofauna and fixed in $4 \%$ buffered formalin. Surficial sediment was collected for analyses of metal concentrations, \% silt/clay and $\%$ organics, and frozen at $-20^{\circ} \mathrm{C}$ pending analysis.

Sample processing. Samples for meiofauna were washed on a $63 \mu \mathrm{m}$ sieve to remove formalin and most of the finer sediment fraction. The meiofauna were then extracted using elutriation in fresh water and decantation through a $63 \mu \mathrm{m}$ seive followed by a flotation extraction using a colloidal silica solution (Ludox TM from DuPont) with a specific gravity of 1.15. Meiofaunal communities in intertidal muds are generally dominated by nematodes and copepods. Our analyses, therefore, are confined to these 2 taxa. Each sample was washed into a lined petri dish and the copepods picked out under a binocular microscope and identified to species, in hanging-drop mounts or by dissection, using a Nomarski interference contrast microscope. The remaining meiofauna were slowly evaporated to anhydrous glycerol, evenly spread on microscope slides and the cover slips ringed with Bioseal. Nematodes were counted and the first 200 specimens encountered in each sample identified to species using conventional bright-field illumination, allowing the total numbers of each species in each sample to be estimated.

Sediment samples were dried at $80^{\circ} \mathrm{C}$. For the determination of metal concentrations dried samples were digested in concentrated $\mathrm{HNO}_{3}$ and, after evaporation, the residues were dissolved in $1 \mathrm{M} \mathrm{HCl}$. Metal concentrations were determined by flame atomic absorption using a Varian Spectr AA20 atomic absorption spectrometer with autosampler. Background correction was used for elements other than $\mathrm{Cu}, \mathrm{Zn}$ and Fe. An air/acetylene flame was used for all metals except $\mathrm{Cr}$, for which nitrous oxide/acetylene flame was used. The $\%$ organic matter in samples was estimated by the loss of weight on ignition at $600^{\circ} \mathrm{C}$ for $8 \mathrm{~h}$, after removal of carbonates by treatment with $8 \% \mathrm{HSO}_{3}$. The \% silt/clay in sediment samples was determined by wet sieving using a $63 \mu \mathrm{m}$ sieve to separate the coarse and fine fractions which were then dried at $95^{\circ} \mathrm{C}$ and weighed.

To account for unmeasured gradients within each creek, such as salinity, a 'distance' factor, the distance of each sampling location from the creek mouth as a proportion of the creek length, was added in the analyses.

\section{DATA ANALYSES}

Analyses of environmental variables. Environmental data were ordinated using a correlation-based principal components analysis (PCA). The significance of 
differences between creeks was tested by applying the randomisation/permutation test ANOSIM (Clarke 1993) to the Euclidean distance matrix underlying the ordination (Clarke \& Green 1988)

Univariate measures of community structure. Univariate measures included: Shannon-Wiener diversity indices calculated using natural logarithms $\left(H^{\prime}\right)$, species richness (Margalef's $d$ ), evenness (Pielou's $J$ ), total abundance $(A)$, and abundance of taxa $(S)$. The significance of differences between creeks was tested using 1 -way ANOVA.

Multivariate analyses of community structure. For the majority of analyses nonparametric multivariate techniques were used. These techniques are discussed in a recent review by Clarke (1993) and are included in PRIMER (Plymouth Routines In Multivariate Ecological Research), a suite of computer programs developed at the Plymouth Marine Laboratory, UK. Ranked lower triangular similarity matrices were constructed using a range of data transformations, the Bray-Curtis similarity measure and group-average sorting. Transformations were used to reduce contributions to similarity by abundant species, and therefore to increase the importance of the less-abundant species in the analyses. Nematodes vary in abundance between single individuals and thousands of specimens within samples, so a fourth root transformation was applied. Copepods vary between single specimens and hundreds of specimens, so a square root transformation was used. Ordination was by nonmetric multidimensional scaling (MDS) (Kruskal \& Wish 1978, Clarke \& Green 1988). Formal significance tests for differences between creeks were performed using the ANOSIM permutation test (Clarke \& Green 1988).
The relationships between multivariate community structure and environmental variables were examined using the BIOENV procedure (Clarke \& Ainsworth 1993) which calculates rank correlations between a similarity matrix derived from biotic data and matrices derived from various subsets of environmental variables, thereby defining suites of variables which 'best explain' the biotic structure. The species contributing to dissimilarities between creeks were investigated using the similarities percentages procedure (SIMPER) (Clarke 1993).

\section{RESULTS}

\section{Environmental variables}

Sediment metal concentrations (Table 1) show that the strong gradient present in the mid-1970s (Bryan \& Gibbs 1983) had not altered appreciably over the intervening years, despite the cessation of mining activity in the Carnon Valley. Sediment concentrations of heavy metals including $\mathrm{Cu}, \mathrm{Zn}, \mathrm{Ag}$ and $\mathrm{Cd}$ were lowest in Percuil Creek and approximately double through St Just, Pill and Mylor Creeks to highest levels in Restronguet Creek, where $\mathrm{Cu}$ concentrations are the highest in the UK (Bryan \& Langstone 1992). Ordination of the metals data by PCA (Fig. 2) shows that Restronguet Creek is clearly separated from all others, which are ordered from Mylor Creek, at the bottom of the ordination, through Pill and St Just Creeks to Percuil Creek. ANOSIM confirms that each creek was significantly different from the others in terms of their sediment metal content $(p<0.03)$ (Table 2$)$. \% silt/clay

Table 1. Means and standard deviations of $\%$ silt/clay $(\% \mathrm{~S} / \mathrm{C}), \%$ organic matter $(\% \mathrm{C})$ and heavy metal concentrations ( $\mu \mathrm{g} \mathrm{g}^{-1} \mathrm{dry}$ weight) in sediments from 5 creeks in the Fal estuary system, November 1991

\begin{tabular}{|c|c|c|c|c|c|c|c|c|c|c|c|c|}
\hline Creek & $\% \mathrm{~S} / \mathrm{C}$ & $\% \mathrm{C}$ & $\mathrm{Ag}$ & $\mathrm{Cd}$ & $\mathrm{Co}$ & $\mathrm{Cr}$ & $\mathrm{Cu}$ & $\mathrm{Fe}$ & $\mathrm{Mn}$ & $\mathrm{Ni}$ & $\mathrm{Pb}$ & $\mathrm{Zn}$ \\
\hline \multicolumn{13}{|c|}{ Restronguet } \\
\hline Mean & 69 & 6.3 & 3.63 & 2.75 & 21.9 & 38.7 & 2532 & 55845 & 539 & 30 & 209 & 3814 \\
\hline $\mathrm{SD}$ & 13 & 1.4 & 0.91 & 1.03 & 4.1 & 4.9 & 575 & 8685 & 44 & 4.7 & 42 & 1295 \\
\hline \multicolumn{13}{|l|}{ Mylor } \\
\hline Mean & 95 & 8.5 & 2.33 & 1.47 & 12.9 & 59.7 & 1272 & 40768 & 395 & 32.8 & 188 & 1431 \\
\hline $\mathrm{SD}$ & 3 & 0.3 & 0.11 & 0.17 & 0.5 & 4.9 & 62 & 1426 & 15 & 1 & 7 & 59 \\
\hline \multicolumn{13}{|l|}{ Pill } \\
\hline Mean & 90 & 9.2 & 1.43 & 1.35 & 11.3 & 43.5 & 697 & 33603 & 282 & 26.9 & 142 & 1006 \\
\hline $\mathrm{SD}$ & 4 & 0.4 & 0.06 & 0.34 & 0.2 & 5.1 & 19 & 1074 & 13 & 0.9 & 8 & 69 \\
\hline \multicolumn{13}{|l|}{ St Just } \\
\hline Mean & 81 & 12.8 & 0.62 & 0.85 & 9.51 & 44 & 332 & 29703 & 249 & 26.6 & 93.9 & 624 \\
\hline $\mathrm{SD}$ & 7 & 4.4 & 0.08 & 0.07 & 0.54 & 4.9 & 33 & 2812 & 10 & 1.3 & 8.8 & 33 \\
\hline \multicolumn{13}{|l|}{ Percuil } \\
\hline Mean & 92 & 8.7 & 0.32 & 0.32 & 7.87 & 49.6 & 165 & 31647 & 221 & 28.9 & 72.8 & 302 \\
\hline SD & 5 & 1.1 & 0.07 & 0.09 & 0.47 & 4 & 34 & 7863 & 39 & 0.9 & 4.5 & 62 \\
\hline
\end{tabular}




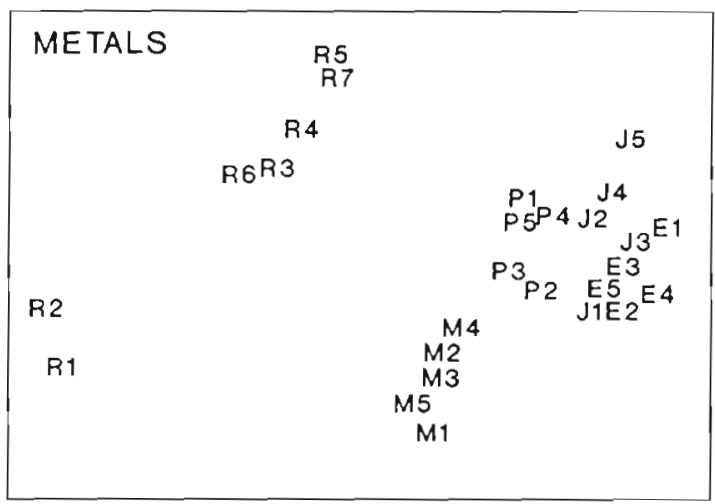

Fig. 2. PCA ordination of metals data from Restronguet ( $R$ ), Mylor (M), Pill (P), St Just (J) and Percuil (E) Creeks

Table 2. Results of pairwise tests from ANOSIM for significant differences in environmental data between creeks

\begin{tabular}{|llc|}
\hline Creeks compared & \multicolumn{1}{c}{$\mathrm{R}$} & $\mathrm{p}$ \\
\hline Restronguet, Mylor & 0.667 & 0.001 \\
Restronguet, Pill & 0.677 & 0.003 \\
Restronguet, St Just & 0.823 & 0.001 \\
Restronguet, Percuil & 0.858 & 0.001 \\
Mylor, Pill & 0.98 & 0.008 \\
Mylor, St Just & 0.94 & 0.008 \\
Mylor, Percuil & 1 & 0.008 \\
Pill, St Just & 0.416 & 0.008 \\
Pill, Percuil & 0.868 & 0.008 \\
St Just, Percuil & 0.324 & 0.024 \\
\hline
\end{tabular}

varied little between samples, although it was lowest at the 2 sites nearest to the mouth of Restronguet Creek. The sediments in St Just Creek had a higher \% organic carbon than did sediments from other creeks.

\section{Univariate measures of nematode and copepod community structure}

Univariate measures for both nematode and copepod data vary significantly between creeks, with the exception of nematode evenness $(J)$ (Figs. 3 \& 4 , Table 3). Although the nematode communities in Restronguet and Mylor Creeks have significantly lower diversity $\left(H^{\prime}\right)$, numbers of genera $(S)$ and species richness (d) than do those in Pill, St Just and Percuil Creeks, univariate measures of community structure do not show any significant differences within these 2 groups (Fig. 3). Other than a reduction in abundance $(A)$ in Restronguet Creek univariate measures of copepod community structure in the various creeks do not reveal a pattern that can be related to the gradient in sediment metal concentrations (Fig. 4).

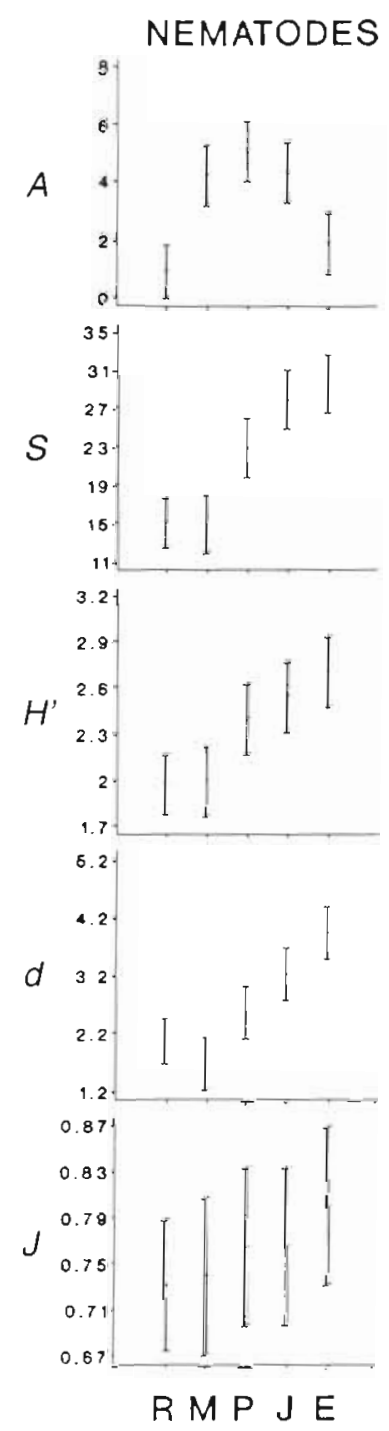

Fig. 3. Means and $95 \%$ pooled confidence intervals for univariate measures of nematode community structure in Restronguet (R), Mylor (M), Pill (P), St Just (J) and Percuil (E) Creeks. A: abundance (thousands of individuals cor $\mathrm{e}^{-1}$ ); $S$ : number of genera; $H^{\prime}$. Shannon-Wiener diversity; d: Margalef's $d_{i} J$ : Pielou's $J$

Table 3. F-ratios and significance levels (from $F_{4.22}$ ) from 1-way ANOVA tests for differences between creeks in various univariate measures of community structure (see text)

\begin{tabular}{|crccc|}
\hline Univariate & \multicolumn{2}{c}{ Nematodes } & \multicolumn{2}{c|}{ Copepods } \\
measure & $F$ & $\mathrm{p}$ & $F$ & $\mathrm{p}$ \\
\hline $\mathrm{A}$ & 14.855 & 0.0000 & 4.586 & 0.0076 \\
$S$ & 24.126 & 0.0000 & 6.840 & 0.0010 \\
$H^{\prime}$ & 9.811 & 0.0001 & 5.127 & 0.0045 \\
$d$ & 17.831 & 0.0000 & 5.217 & 0.0041 \\
$J$ & 0.750 & 0.5684 & 3.147 & 0.0345 \\
\hline
\end{tabular}




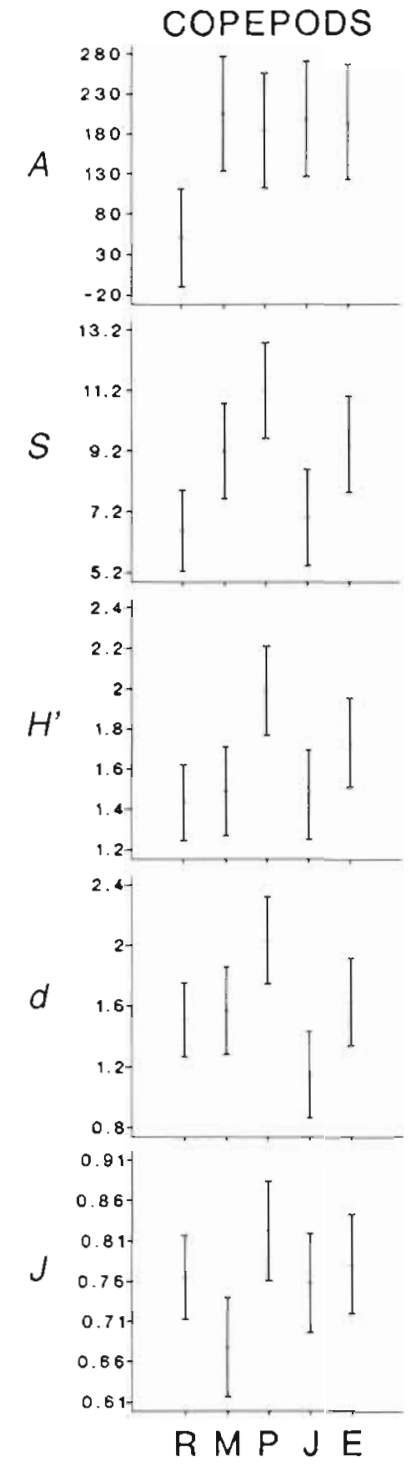

Fig. 4. Means and $95 \%$ pooled confidence intervals for univariate measures of copepod community structure in Restronguet (R), Mylor (M), Pill (P), St Just (J) and Percuil (E) Creeks. A: abundance (individuals $\operatorname{cor}^{-1}$ ); $S$ : number of genera; $H^{\prime}$ : Shannon-Wiener diversity; $d$ : Margalef's $d$; $J$ : Pielou's $J$

\section{Multivariate analyses}

MDS ordinations (Fig, 5) show a gradation in nematode community structure. Restronguet Creek is clearly separated from all others, which are ordered from Mylor Creek, at the bottom of the ordination, through Pill and St Just Creeks to Percuil Creek, i.e. in an order consistent with increasing metal concentrations. Samples from within Restronguet Creek are also ordered, with samples from the head of the

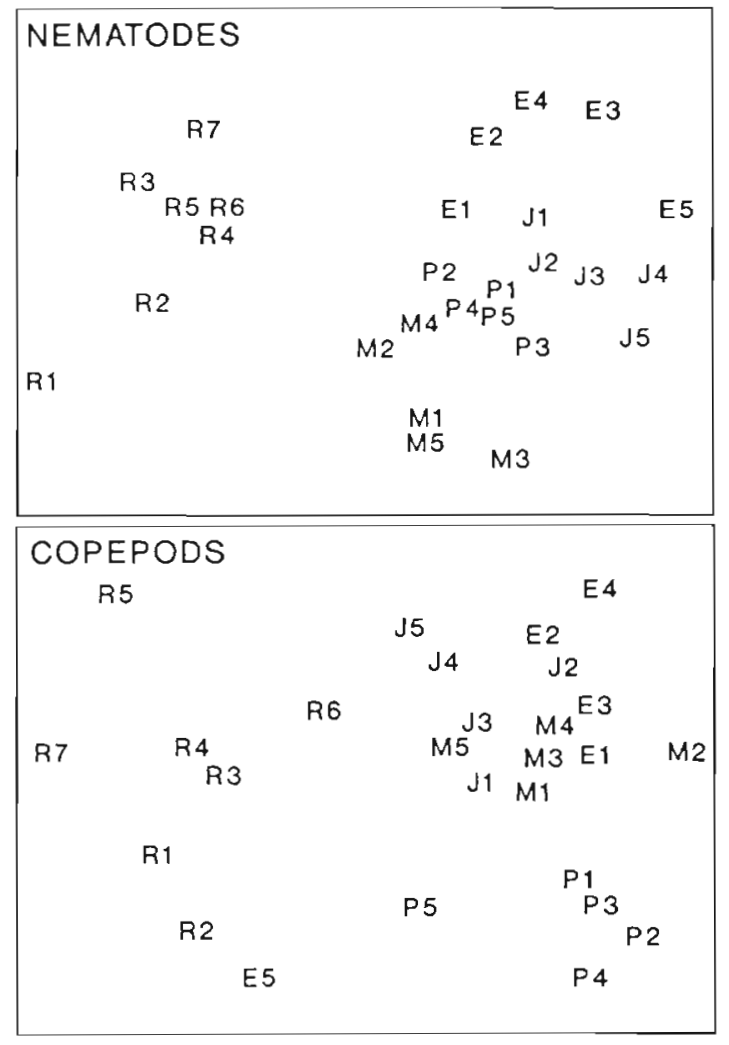

Fig. 5. Multidimensional scaling ordinations for fourth root transformed nematode abundance (stress $=0.13$ ) and square root transformed copepod abundance (stress $=0.14$ ) in Restronguet (R), Mylor (M), Pill (P). St Just (J) and Percuil (E) Creeks

creek (i.e. nearest the source of input) at the bottom. Other than separation of the community in Restronguet Creek from those in other creeks, ordination of the transformed copepod data does not present a pattern that is as readily related to a gradient as is that from the nematode data. ANOSIM confirms that the nematode and copepod communities in all creeks are significantly $(\mathrm{p}<0.05)$ different from each other (Table 4).

A standard product-moment correlation analysis (Table 5) of environmental data from the survey indicates that sediment levels of all metals other than $\mathrm{Cr}$ and $\mathrm{Ni}$ are highly correlated $(>0.95)$ with $\mathrm{Cu}$ levels. Thus only concentrations of $\mathrm{Cu}, \mathrm{Cr}$ and $\mathrm{Ni}$ were used in the BIOENV analysis, along with the other variables $\%$ silt/clay, \% organic carbon and proportional distance from the creek mouth. Results of the analyses are summarised in Table 6.

The highest rank correlation with fourth root transformed nematode abundance data (0.77) occurs with the single variable $\mathrm{Cu}$, and including extra variables 
Table 4. Results of pairwise tests from ANOSIM for significant differences in community structure between creeks. Nematode data fourth root transformed, copepod data square root transformed

\begin{tabular}{|llccc|}
\hline $\begin{array}{l}\text { Univariate } \\
\text { measure }\end{array}$ & \multicolumn{2}{c}{ Nematodes } & \multicolumn{2}{c|}{ Copepods } \\
& $F$ & $\mathrm{p}$ & $F$ & $\mathrm{p}$ \\
\hline Restronguet, Mylor & 0.902 & 0.001 & 0.889 & 0.001 \\
Restronguet, Pill & 0.93 & 0.001 & 0.917 & 0.001 \\
Restronguet, St Just & 0.985 & 0.001 & 0.759 & 0.001 \\
Restronguet, Percuil & 0.965 & 0.001 & 0.771 & 0.003 \\
Mylor, Pill & 0.948 & 0.008 & 0.684 & 0.008 \\
Mylor, St Just & 0.976 & 0.008 & 0.536 & 0.008 \\
Mylor, Percuil & 0.876 & 0.008 & 0.316 & 0.008 \\
Pill, St Just & 0.752 & 0.008 & 0.876 & 0.008 \\
Pill, Percuil & 0.784 & 0.008 & 0.544 & 0.008 \\
St Just, Percuil & 0.508 & 0.024 & 0.412 & 0.008 \\
\hline
\end{tabular}

degrades this correlation, confirming that differences between nematode communities in different creeks are linked to levels of heavy metals in the sediments. For square root transformed copepod abundances the highest rank correlation is only 0.51 , with 2 variables $\mathrm{Cu}$ and \% silt/clay. Therefore copepod community structure is not particularly well explained by the measured environmental variables.

As the concentrations of most metals are correlated with Cu, MDS plots overlaid with symbols proportional in size to $\mathrm{Cu}$ concentration (Fig. 6) allow one to visualise the relationship between metal levels and community structure. The nematode community in each creek can be distinguished on the basis of levels of $\mathrm{Cu}$ and metals in the sediments, with the community in Restronguet Creek clearly separated from the rest, and samples in both groups arranged from bottom to top of the ordination according to heavy metal concentra-
Table 6. Summary of results from BIOENV. Combinations of variables, $k$ at a time, giving the highest rank correlations between biotic and abiotic similarity matrices. Nematode data fourth root transformed, copepod data square root transformed. -: lower correlations omitted from the table. $\%$ C: \% organic matter; \% S/C: \% silt/clay

\begin{tabular}{|c|c|c|c|}
\hline$k$ & \multicolumn{3}{|c|}{ Best variable combinations } \\
\hline \multicolumn{4}{|c|}{ Nematodes } \\
\hline 1 & $\begin{array}{c}\mathrm{Cu} \\
0.77\end{array}$ & $\begin{array}{l}\% \mathrm{C} \\
0.28\end{array}$ & 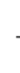 \\
\hline 2 & $\begin{array}{c}\mathrm{Cu}, \% \mathrm{~S} / \mathrm{C} \\
0.71\end{array}$ & $\begin{array}{l}\mathrm{Cu}_{1} \mathrm{Ni} \\
0.66\end{array}$ & - \\
\hline 3 & $\begin{array}{c}\mathrm{Cu}, \mathrm{Ni} \% \mathrm{~S} / \mathrm{C} \\
0.67\end{array}$ & - & \\
\hline \multicolumn{4}{|c|}{ Copepods } \\
\hline 1 & $\begin{array}{c}\mathrm{Cu} \\
0.45\end{array}$ & $\begin{array}{l}\% C \\
0.31\end{array}$ & - \\
\hline 2 & $\begin{array}{c}\mathrm{Cu}, \% \mathrm{~S} / \mathrm{C} \\
0.51\end{array}$ & $\begin{array}{c}\mathrm{Cu}, \% \mathrm{C} \\
0.36\end{array}$ & - \\
\hline 3 & $\begin{array}{c}\mathrm{Cu}, \% \mathrm{~S} / \mathrm{C}, \text { Distance } \\
0.43\end{array}$ & - & \\
\hline
\end{tabular}

tions. The relationship between sediment metals and copepod community structure is less clear.

SIMPER analyses of transformed nematode and copepod abundance data allow the examination of the species which contribute to the dissimilarity between creeks (Table 7). The nematode community in Restronguet Creek is separated from those in all other creeks by a general reduction or absence of a range of nematode species and the presence of relatively high numbers of a few species including Tripyloides gracilis, Desmodora communis and Leptolaimus papilliger. Mylor Creek is separated from Pill and St Just Creeks by the presence of relatively high abundances of Dap-

Table 5. Pairwise correlations between environmental variables. Values in bold type indicate correlations $>0.95 . \% \mathrm{~S} / \mathrm{C}$ : $\%$ silt/clay; \% C: \% organic matter

\begin{tabular}{|c|c|c|c|c|c|c|c|c|c|c|c|c|}
\hline & $\mathrm{Ag}$ & $\mathrm{Cd}$ & $\mathrm{Co}$ & $\mathrm{Cr}$ & $\mathrm{Cu}$ & $\mathrm{Fe}$ & $\mathrm{Mn}$ & $\mathrm{Ni}$ & $\mathrm{Pb}$ & $\mathrm{Zn}_{n}$ & Distance & $\% \mathrm{~S} / \mathrm{C}$ \\
\hline $\mathrm{Cd}$ & 0.932 & & & & & & & & & & & \\
\hline $\mathrm{Co}$ & 0.9625 & 0.9515 & & & & & & & & & & \\
\hline $\mathrm{Cr}$ & -01381 & -0.2155 & -0.297 & & & & & & & & & \\
\hline $\mathrm{Cu}$ & 0.9873 & 0.9392 & 0.9869 & -0.222 & & & & & & & & \\
\hline $\mathrm{Fe}$ & 0.9281 & 0.8889 & 0.9452 & -0.149 & 0.9506 & & & & & & & \\
\hline Mn & 0.9668 & 0.886 & 0.9502 & -0.179 & 0.98 & 0.9467 & & & & & & \\
\hline $\mathrm{Ni}$ & 0.5836 & 0.5081 & 0.4811 & 0.5629 & 0.5263 & 0.5969 & 0.502 & & & & & \\
\hline $\mathrm{Pb}$ & 0.9642 & 0.8968 & 0.889 & 0.0144 & 0.9225 & 0.8609 & 0.9073 & 0.6408 & & & & \\
\hline $\mathrm{Zn}$ & 0.9511 & 0.9652 & 0.9895 & -0.284 & 0.9774 & 0.9449 & 0.9304 & 0.5025 & 0.8702 & & & \\
\hline Distance & -0.209 & -0.2646 & -0.1662 & -0.427 & -0.1597 & -0.235 & -0.129 & -0.648 & -0.283 & -0.1841 & & \\
\hline$\therefore S / C$ & -0.362 & -0.3026 & -0.4621 & 0.7197 & -0.4477 & -0.347 & -0.455 & 0.3319 & -0.193 & -0.4247 & -0.4916 & \\
\hline$\% \mathrm{C}$ & -0.5216 & -0.4029 & -0.4849 & 0.1281 & -0.5324 & -0.516 & -0.543 & -0.24 & -0.44 & -0.4745 & -0.0123 & 0.3617 \\
\hline
\end{tabular}



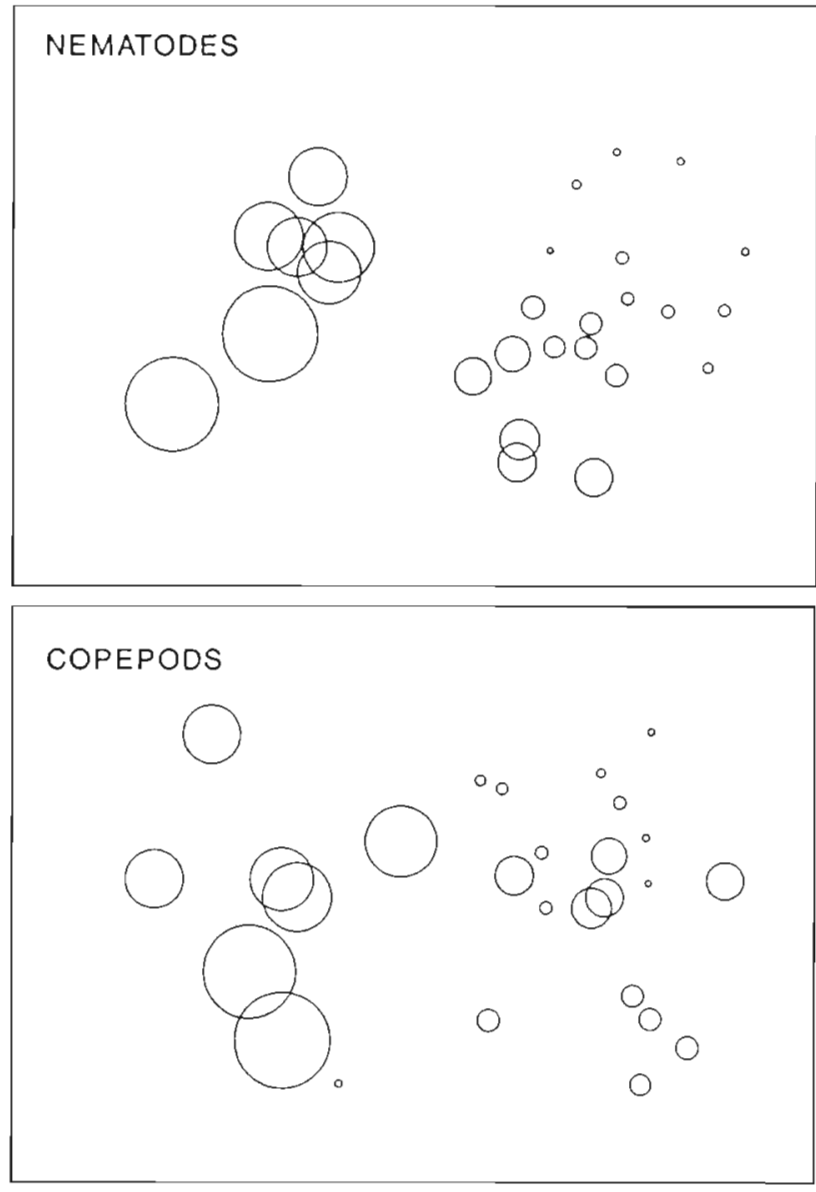

Fig. 6. Multidimensional scaling ordinations, as in Fig. 5, overlaid with circles proportional in diameter to sediment $\mathrm{Cu}$ concentration

tonema procerum, Metachromadora vivipara and Calomicrolaimus honestus in Mylor and a general increase in abundance of a broad range of species in creeks with lower sediment metal concentrations. In comparison with the nematode community in Pill Creek, that in St Just Creek differs in the main due to changes in the abundance of species common to both creeks, such as Aponema torosa, Calomicrolaimus honestus, Sabatieria pulchra and Paracanthonchus heterodontus which are more abundant in Pill Creek, and Leptolaimus limicolus, Anoplostoma vivipara and Terschellingia species, which are more abundant in St Just Creek. Some species including Daptonema setosum and Paracomesoma dubium are absent from Pill Creek. In comparison with other creeks Percuil has more species but lower abundances of individual species. The general pattern therefore appears to be one of increasing species diversity with decreasing metal concentrations, but with changes in abundances of individual species contributing to the dissimilarity between creeks in a way that is not readily interpretable, although the general trend is an increase in numbers, with the exception of Percuil Creek.

The majority of copepod species contributing highly to dissimilarities between Restronguet Creek and the other creeks are absent from, or occur in low numbers in, Restronguet Creek. Examples are Enhydrosoma gariene, Microarthridion fallax, Platychelipus littoralis and Mesochra lilljeborgi. The only species occurring in higher numbers in Restronguet Creek is Stenhelia palustris. Dissimilarities between other creeks generally result from changes in relative abundances of more abundant species such as Microarthridion fallax, Tachidius discipes and Robertsonia celtica, and sporadic absences of less common species such as Stenhelia elizabethae from St Just Creek.

\section{DISCUSSION}

The majority of studies with meiofauna and metals have been in vitro laboratory toxicity studies with copepods and nematodes (Coull \& Chandler 1992), which have tended to show that metals as toxicants have either lethal or sublethal (reductions in fecundity, increased developmental time) effects which tend to increase with increased metal concentrations. Thus a decrease in diversity is to be expected as a community response to metal pollution. Only 2 field studies have been reported which can be related to our studies on the Fal estuary complex. Both deal with shallow sublittoral sediments off New York, USA (Tietjen 1977. 1980). In the former study no relationship between sediment metal concentrations and nematode species diversity was demonstrated, but there were many other confounding factors such as differences in sediment composition and the organic loading of the sediments. In the latter study (Tietjen 1980) a clear relationship between increased metal concentrations and decreased nematode diversity was demonstrated. Although some changes in univariate measures of community structure, such as the reduction in diversity of nematodes in Restronguet and Mylor Creeks, can be related to changes in sediment metal concentrations, the present study suggests that such derived measures conceal more than they reveal about changes in community structure between creeks. Multivariate analyses, however, suggest that nematode community structure changes in a smooth and ordered fashion with increasing sediment metal concentrations. Changes in copepod community structure between creeks are not as ordered.

Multivariate analyses indicate a strong relationship between nematode community structure and metal concentrations in the Fal system. BIOENV analyses 
Table 7. Summary of similarities terms (SIMPER) analysis. Differences ( $<$ and $>$ ) in average abundances (ind. core ${ }^{-1}$ ) of species contributing to dissimilarities between consecutive creeks along the metals gradiant. A cut-off at a cumulative \% dissimilarity of $70 \%$ was applied

\begin{tabular}{|c|c|c|c|c|c|c|c|c|c|}
\hline & Restronguet & & Mylor & & Pill & & St Just & & Percuil \\
\hline \multicolumn{10}{|l|}{ Nematodes } \\
\hline Metachromadora vivipara & 1 & $<$ & 1697 & & & & 843 & $>$ & 493 \\
\hline Calomicrolaimus honestus & 2 & $<$ & 593 & & 251 & $>$ & 57 & & \\
\hline Daptonema normandicum & 6 & $<$ & 393 & & & & 108 & $>$ & 18 \\
\hline Terschellingia longicaudata & 0 & $<$ & 155 & & 130 & $<$ & 367 & & \\
\hline Terschellingia communis & 4 & $<$ & 256 & $>$ & 104 & $<$ & 308 & & \\
\hline Theristus acer & 34 & $>$ & 0 & $<$ & 88 & $>$ & 54 & $>$ & 9 \\
\hline Desmodora communis & 44 & $>$ & 0 & & & & & & \\
\hline Tripyloides gracilis & 278 & $>$ & 43 & & 48 & $>$ & 4 & & \\
\hline Daptonema setosum & 0 & $<$ & 46 & $>$ & 0 & $<$ & 23 & $>$ & 10 \\
\hline Chromadora macrolaima & 78 & $>$ & 13 & $<$ & 130 & & 215 & $>$ & 56 \\
\hline Hypodontolaimus balticus & 21 & $>$ & 6 & $<$ & 58 & $>$ & 23 & $>$ & 1 \\
\hline Terschellingia sp. & & & 0 & $<$ & 322 & & 218 & $>$ & 16 \\
\hline Aponema torosa & & & 15 & $<$ & 310 & $>$ & 5 & $<$ & 8 \\
\hline Daptonema procerum & & & 67 & $>$ & 14 & $<$ & 18 & $<$ & 20 \\
\hline Paracanthonchus heterodontus & & & 13 & $<$ & 100 & & 36 & $>$ & 19 \\
\hline Desmolaimus zeelandicus & & & 5 & $<$ & 55 & $<$ & 76 & $>$ & 20 \\
\hline Molgolaimus demani & & & 149 & $<$ & 687 & & 728 & $>$ & 56 \\
\hline Leptolaimus limicolus & & & & & 12 & $<$ & 199 & $>$ & 42 \\
\hline Anoplostoma viviparum & & & & & 6 & $<$ & 51 & & \\
\hline Paracomesoma dubium & & & & & 0 & $<$ & 23 & & \\
\hline Preacanthonchus punctatus & & & & & 10 & $<$ & 30 & $>$ & 18 \\
\hline Chromadorita tentabunda & & & & & 4 & $<$ & 17 & $<$ & 21 \\
\hline Thalassomonhystera parva & & & & & & & 0 & $<$ & 15 \\
\hline Axonolaimus paraspinosus & & & & & & & 80 & $>$ & 32 \\
\hline \multicolumn{10}{|l|}{ Copepods } \\
\hline Enhydrosoma gariene & 0 & $<$ & 48 & $>$ & 32 & & 9 & $<$ & 22 \\
\hline Microarthridion fallax & 14 & $<$ & 85 & $>$ & 33 & $<$ & 75 & $>$ & 54 \\
\hline Platychelipus littoralis & 1 & $<$ & 33 & $<$ & 50 & $>$ & 8 & & \\
\hline Robertsonia celtica & 0 & $<$ & 9 & & 3 & $<$ & 22 & $>$ & 10 \\
\hline Stenhelia palustris & 14 & $>$ & 5 & & & & & & \\
\hline Amphiascoides limicola & & & 0 & $<$ & 12 & & & & \\
\hline Mesochra lilljeborgi & & & 2 & $<$ & 15 & $>$ & 0 & & \\
\hline Paronychocamptus curticaudatus & & & 0 & $<$ & 6 & & & & \\
\hline Enhydrosoma longifurcatum & & & 0 & $<$ & 6 & & & & \\
\hline Tachidius discipes & & & & & 0 & $<$ & 30 & $>$ & 8 \\
\hline Pseudobradya curticorne & & & & & 11 & $<$ & 42 & $<$ & 45 \\
\hline Pseudobradya sp. & & & & & & & 0 & $<$ & 25 \\
\hline
\end{tabular}

from the German Bight (Gee et al. 1992) also implicate heavy metals as determinants of meiobenthic community structure, although in this study confounding effects of changes in sediment structure and depth tended to obscure any relationships between meiofaunal community structure and levels of pollutants. In the present study the sampling design attempted to eliminate such confounding factors as far as possible. Although metal concentrations are an important factor influencing copepod community structure in the Fal system, BIOENV indicates that other factors are also of significance. \% silt/clay is one, even though there is little variation in sediment structure between creeks.

Multivariate analyses also suggest the possibility of threshold levels in meiofaunal responses to heavy metal pollution. In Restronguet Creek, where sediment copper concentrations are in the region of $2500 \mu \mathrm{g} \mathrm{g}^{-1}$, the nematode and copepod communities are very different to those in all the other creeks, in which sediment copper concentrations range from 100 to $1200 \mu \mathrm{g}$ $\mathrm{g}^{-1}$. It is unlikely however that the actual value of such a threshold would be of universal significance, as the communities in these creeks must be adapted to survive high metal concentrations. Even in Percuil Creek the levels of copper are generally still an order of magnitude higher than those found in genuinely unpolluted sites (Bryan \& Gibbs 1983). Luoma et al. (1983) showed that tolerance to $\mathrm{Cu}$ in populations of Macoma balthica and the copepod Acartia clausi varied as much as 10 -fold over short distances. Rygg (1985) suggested 
that a $\mathrm{Cu}$ concentration of $200 \mu \mathrm{g} \mathrm{g}^{-1}$ represented a threshold concentration for polychaete communities.

Laboratory studies have shown that acute and sublethal toxicity of metals to a variety of meiofauna is dependant not only on the chemical form of a metal, but also on other factors including temperature (Verriopoulos 1981, Lehtinen et al. 1984, Vranken et al. 1989), salinity (Bengtsson \& Bergstrom 1987) and food (Verriopoulos \& Moraitou-Apostolopolou 1989). The question of bioavailability and metal toxicity to the benthos is enormously complicated and is not necessarily reflected in measurements of total concentrations. Modifying processes include the mobilisation of metals to the interstitial water and their chemical speciation, chemical transformations such as methylation of metals like $\mathrm{As}$ and $\mathrm{Pb}$, the control exerted by major sediment components such as oxides of Fe and organic matter to which metals may bind preferentially, and competition between chemically similar metals such as $\mathrm{Cu}$ and $\mathrm{Ag}, \mathrm{Zn}$ and $\mathrm{Cd}$, for uptake sites in organisms. These processes are further influenced by physical factors such as bioturbation, salinity, redox potential and $\mathrm{pH}$ (Bryan \& Langston 1992). Thus it is often difficult to relate the results of in vitro experiments to natural situations. Uptake of metals in macrofaunal species tends to result from uptake through body surfaces (Bryan 1985) or ingestion of particles (Harvey \& Luoma 1985). The cuticle of nematodes is known to be a site of uptake for metals (Howell 1983). Mucous substances secreted by nematodes are cabable of binding metals (Howell \& Smith 1983) and it has been suggested (Riemann \& Schrage 1978) that mucus is used by many nematode species as a part of their feeding mechanism. Acid mucopolysaccharides secreted by bacteria are also cabable of binding metals (Harvey \& Luoma 1985, Decho 1990) and it is likely that, as many nematodes and copepods are bacterial feeders (Rieper 1982, Jensen 1987), this is another route by which meiofauna assimilate metals.

There is evidence from the macrofauna that in areas of high metal concentrations, their effects may be ameliorated by the development of tolerance mechanisms in some species (Grant et al. 1989, Bryan \& Langston 1992) and the evolution of tolerant strains in others (Hately et al. 1989). Such processes may also be found in the meiofauna. Metals occur most abundantly in the tissues of surface-dwelling meiofauna (Frithsen 1984), and Howell $(1982 a, b, 1983,1984)$ showed that metal levels are higher in meiofauna from polluted sites and that specimens of Enoplus brevis from a polluted site were less sensitive to metals than specimens from an unpolluted site. Our data suggest that some species, such as Ptycholaimellus ponticus, Sabatieria pulchra, Molgolaimus demani and Axonolaimus paraspinosus, can tolerate the whole range of metal concentrations and may therefore have some form of tolerance mechanism. Tripyloides gracilis and Desmodora communis are most common in, but not restricted to, Restronguet Creek, and may therefore have developed tolerant strains. Tietjen (1980) found that S. pulchra and T. gracilis were relatively abundant at a site with high sediment metal concentrations. Other species, such as Calomicrolaimus honestus, Daptonema normandicum and Terschellingia species, common and often dominant in other creeks, are absent from Restronguet Creek, suggesting that they are incapable of adapting to such extreme levels of metal pollution. Nematodes appear to be more sensitive to metal pollution than copepods. This is not unexpected, as nematode life histories are more closely integrated with the sediment, whereas the copepod community contains many epibenthic species. Indeed it is the epibenthic species such as Pseudobradya species, Tachidius discipes and Microarthridion fallax, along with the tube-dwelling Stenhelia palustris, which are found in all creeks. Endobenthic species such as Enhydrosoma gariene, Robertsonia celtica and Mesochra lilljeborgi, common in other creeks, are absent from Restronguet Creek.

Acknowledgements. This work was funded by the U.K. Ministry of Agriculture, Fisheries and Food as part of an evaluation of the use of meiofauna in pollution monitoring programmes (project no. AE0514). We acknowledge A. Rowden and $\mathrm{S}$. Widdicombe and others from Plymouth Marine Laboratory for sampling and technical assistance, G. Bryan and $W$. Langston for advice and C. Manley for the determination of sediment metals.

\section{LITERATURE CITED}

Bengtsson, B.-E., Bergström, B. (1987). A flowthrough fecundity test with Nitocra spinipes (Harpacticoidea, Crustacea) for aquatic toxicity. Ecotoxicol. environ. Saf. 14: 260-268

Bryan, G. W. (1976). Heavy metal contamination in the sea. In: Johnston, J. (ed.) Marine pollution. Academic Press, London, p. 185-302

Bryan, G. W. (1985). Bioavailability and the effects of heavy metals in marine deposits. In: Ketchum, B. H., Capuzzo, J. M., Burt, W. V., Duedall I. W., Park, P. K., Kester, D. R. (eds.) Wastes in the ocean, Vol. 6, Nearshore waste disposal. John Wiley \& Sons, New York, p. 42-79

Bryan, G. W. Gibbs P. E. (1983). Heavy metals in the Fal Estuary, Cornwall: a study of long-term contamination by mining waste and its effects on estuarine organisms. Occasional Publication No. 2, Mar. Biol. Ass. U.K., Plymouth

Bryan, G. W., Langston, W. J. (1992). Bioavailability, accumulation and effects of heavy metals in sediments with special reference to U.K. estuaries: a review. Environ. Pollut. 76: $89-131$

Clarke, K. R. (1993). Non-parametric multivariate analyses of changes in community structure. Aust. J. Ecol. 18: $117-143$

Clarke, K. R., Ainsworth, M. (1993). A method of linking multivariate community structure to environmental variables Mar. Ecol. Prog. Ser. 92: 205-219 
Clarke, K. R., Green, R. H. (1988). Statistical design and analysis for a 'biological effects' study. Mar. Ecol. Prog. Ser. 46: 213-226

Coull, B. C., Chandler, G. T. (1992). Pollution and meiofauna: field, laboratory and mesocosm studies. Oceanogr. mar. Biol. A. Rev. 30: 191-271

Decho, A. W. (1990). Microbial exopolymer secretions in ocean environments: their role(s) in food webs and marine processes. Oceanogr. mar. Biol. A. Rev. 28: 73-153

Frithsen, J. B. (1984). Metal incorporation by benthic fauna: Relationships to sediment inventory. Estuar. coast Shelf Sci. 19: 523-539

Gee, J. M., Austen, M., De Smet, G., Ferrero, T., McEvoy, A., Moore, S., Van Gausbeki, D., Vincx, M., Warwick, R. M. (1992). Soft sediment meiofauna community responses to environmental pollution gradients in the German Bight and at a drilling site off the Dutch coast. Mar. Ecol. Prog Ser. 91: 289-302

Grant, A., Hately, J. G., Jones, N. V. (1989). Mapping the ecological impact of heavy metals in the estuarine polychaete Nereis diversicolor using inherited metal tolerance. Mar. Pollut. Bull. 20; 235-238

Harvey, R. W., Luoma, S. N. (1985). Effect of adherent bacteria and bacterial extracellular polymers upon assimilation by Macoma balthica of sediment-bound $\mathrm{Cd}, \mathrm{Zn}$ and $\mathrm{Ag}$. Mar. Ecol. Prog. Ser. 22: 281-289

Hately, J. G., Grant, A., Jones, N. V. (1989). Heavy metal tolerance in estuarine populations of Nereis diversicolor. In: Ryland, J. S., Tyler, P. A. (eds.) Reproduction, genetics and distribution of marine organisms. Proc. 23rd Eur. mar. Biol. Symp., p. 379-384

Heip, C., Warwick, R. M., Carr, M. R., Herman, P. M. J., Huys, R., Smol, N., Van Holsbeke, K. (1988). Analysis of community attributes of the benthic meiofauna of Friersfjord/Langesundfjord. Mar. Ecol. Prog. Ser. 46: 171-180

Howell, R. (1982a). The secretion of mucus by marine nematodes (Enoplus spp.): a possible mechanism influencing the uptake and loss of heavy metal pollutants. Nematologia 28: $110-114$

Howell, R. (1982b). Levels of heavy metal pollutants in two species of marine nematodes. Mar. Pollut. Bull. 13: $396-398$

Howell, R. (1983). Heavy metals in marine nematodes: uptake, tissue distribution and loss of copper and zinc. Mar. Pollut. Bull. 14: 263-268

This article was submitted to the editor
Howell, R. (1984). Acute toxicity of heavy metals to two species of marine nematodes. Mar. environ. Res. 11: 153-161

Howell, R., Smith. L. (1983). Binding of heavy metals by the marine nematode Enoplus brevis. Nematologia 29: 39-48

Jensen, P. (1987). Feeding ecology of free-living aquatic nematodes. Mar. Ecol. Prog. Ser. 35: 187-196

Kruskal, J. B., Wish, M. (1978). Multidimensional scaling Sage Publications, Beverly Hills

Lehtinen, K.-J., Bengtsson, B.-E., Bergstrom, B. (1984). The toxicity of effluents from a $\mathrm{TiO}_{2}$ plant to the harpacticoid copepod Nitocra spinipes Boeck. Mar. environ. Res. 12: $272-283$

Luoma, S. N., Cain, D. J., Ho, K., Hutchinson, A. (1983). Variable tolerance to copper in two species from San Francisco bay. Mar. environ. Res. 10: 209-222

Riemann, F., Schrage, M. (1978). The mucus-trap hypothesis on feeding of aquatic nematodes and implications for biodegradation and sediment texture. Oecologia 34: 75-88

Rieper, M. (1982). Feeding preferences of marine harpacticoid copepods for various species of bacteria. Mar. Ecol. Prog. Ser. 7: 303-307

Rygg, B. (1985). Effect of sediment copper on benthic fauna. Mar. Ecol. Prog. Ser. 25: 83-89

Tietjen, J. H. (1977). Population distribution and structure of the free-living nematodes of Long Island Sound. Mar. Biol. 43: $123-136$

Tietjen, J. H. (1980). Population structure and species distribution of the free-living nematodes inhabiting sands of the New York Bight apex. Estuar. coast. mar. Sci. 10:61-73

Verriopoulos, G. (1980). La toxicité du Cr sur le copépode harpacticöide Tisbe holothuriae en relation avec la température. $V^{\text {es }}$ Journées Etudes Pollutions. Comm. Int. Explor. Mer Méd., Cagliari, p. 797-802

Verriopoulos, G., Moraitou-Apostolopolou, M. (1989). Toxicity of zinc to the marine copepod Tisbe holothuriae; the importance of the food factor. Arch. Hydrobiol. 114: $457-463$

Vranken, G., Tire, C., Heip, C. (1989). Effect of temperature and food on hexavalent chromium toxicity to the marine nematode Monhystera disjuncta. Mar. environ. Res. 27: $127-136$

Warwick, R. M. (1993). Environmental impact studies on marine communites: pragmatical considerations. Aust. J. Ecol. 18: 63-80

Manuscript first received: September 2, 1993

Revised version accepted: December 6, 1993 